\title{
Comprehensive health assessment of green turtles Chelonia mydas nesting in southeastern Florida, USA
}

\author{
Annie Page-Karjian ${ }^{1, *}$, Ryan Chabot ${ }^{2}$, Nicole I. Stacy ${ }^{3}$, Ashley S. Morgan ${ }^{1}$, \\ Roldán A. Valverde ${ }^{4,5}$, Sydney Stewart ${ }^{4}$, Christina M. Coppenrath ${ }^{6}$, \\ Charles A. Manire ${ }^{6}$, Lawrence H. Herbst ${ }^{7}$, Christopher R. Gregory $^{8}$, \\ Branson W. Ritchie ${ }^{8}$, Justin R. Perrault ${ }^{6}$
}

${ }^{1}$ Florida Atlantic University, Harbor Branch Oceanographic Institute, Fort Pierce, Florida 34946, USA

${ }^{2}$ Inwater Research Group, Jensen Beach, Florida 34957, USA

${ }^{3}$ Aquatic, Amphibian, and Reptile Pathology Program, Department of Comparative, Diagnostic, and Population Medicine, University of Florida College of Veterinary Medicine, Gainesville, Florida 32608, USA

${ }^{4}$ Southeastern Louisiana University, Hammond, Louisiana 70402, USA

${ }^{5}$ Sea Turtle Conservancy, Gainesville, Florida 32609, USA

${ }^{6}$ Loggerhead Marinelife Center, Juno Beach, Florida 33408, USA

${ }^{7}$ Albert Einstein College of Medicine, Bronx, New York 10461, USA

${ }^{8}$ Infectious Diseases Laboratory, College of Veterinary Medicine, University of Georgia, Athens, Georgia 30602, USA

\begin{abstract}
Important indicators of population health needed for large-scale sea turtle population recovery efforts include demographics, disease and mortality trends, condition indices, and baseline blood data. With this comprehensive health assessment of adult female green sea turtles Chelonia mydas nesting on Juno Beach, Florida, USA, we (1) established baseline health indices; (2) identified individuals with evidence of infection by chelonid alphaherpesviruses 5 and 6 (ChHV5, ChHV6), which are implicated in fibropapillomatosis and respiratory and skin disease, respectively; and (3) compared measured health indices between turtles that did versus those that did not test positive for ChHV5 and/or ChHV6. All 60 turtles included in the study were in good body condition with no external fibropapillomatosis tumors. Hematological and biochemical reference intervals were established. Via quantitative PCR (qPCR), 5/60 turtles (8\%) tested positive for ChHV5, and all turtles were negative for ChHV6. Of 41 turtles tested for antibodies to ChHV5 and ChHV6, $29 \%$ and $15 \%$ tested positive, respectively, and $10 \%$ tested positive for antibodies to both viruses. Notably, there were no statistically significant differences between health variables for nesting turtles that tested positive for ChHV5 DNA versus those that tested negative; and also no differences between turtles that tested positive for ChHV5 or ChHV6 antibodies and those that did not. This suggests that these viruses are enzootically stable in Florida's adult green turtles. This study provides a health profile of nesting green turtles in southeastern Florida applicable to temporal and spatial investigations of this and other populations.
\end{abstract}

KEY WORDS: ChHV5 - ChHV6 - Lung-eye-trachea virus · Serology $\cdot$ Enzootic $\cdot$ Hematology · Plasma chemistry $\cdot$ Haptoglobin

\section{INTRODUCTION}

Green turtles Chelonia mydas are the second most common sea turtle species to nest on the coast of

${ }^{*}$ Corresponding author: cpagekarjian@fau.edu
Florida, USA, after loggerhead turtles Caretta caretta (FWC 2018a). Sea turtles are considered to be sentinel species of environmental health, whereby sea turtle health is thought to reflect the health of the 
ecosystems they inhabit. Thus, examining sea turtle health is an important component of any coastal ecosystem health survey that includes sea turtle developmental, foraging, and/or nesting habitat(s) (Aguirre \& Lutz 2004). Conservation threats to sea turtles in Florida are numerous, and include habitat encroachment and pollution, illegal harvesting, artificial beach lighting and coastal armoring, and human interactions such as entanglement, hook ingestion, and boat strike trauma (FWC 2018b). Diseases, including fibropapillomatosis (FP), also directly threaten sea turtle conservation (Hamann et al. 2010). Important indicators of population health that we can monitor include population demographics, mortality trends, prevalent diseases and stranding causes, and blood data (Deem et al. 2009). Establishing cohort-specific baseline health data within a population is a valuable tool for assessing the overall health of a population, for use as a baseline in longitudinal monitoring efforts, and for use as prognostic indicators in individual health assessments and patient care of stranded turtles (Deem et al. 2009). Such baseline health assessments of a sea turtle population can provide useful science-based information for wildlife and environmental policy management.

FP is a debilitating disease of sea turtles characterized by neoplastic growths on the skin, shell, and/or internal organs, and is enzootic in green turtles in Florida, as is chelonid alphaherpesvirus 5 (ChHV5), the virus associated with FP (Ene et al. 2005). First recorded in the Florida Keys in the 1930s, FP is occurring at increased prevalence in some areas of Florida and is now present in many sea turtle foraging aggregations around the world (Foley 2016, Jones et al. 2016, Reséndiz et al. 2016, Cazabon-Mannette \& Phillips 2017, Cárdenas et al. 2019). Sea turtles with FP are usually diagnosed (via molecular techniques) with or presumed to be infected with ChHV5, which is thought to play an etiological role in FP disease pathogenesis (Herbst et al. 1995, Lackovich et al. 1999). ChHV5 primarily targets the skin, and horizontal transmission likely occurs when tumors of FPaffected turtles undergo sloughing of virally infected epidermal cells into the environment (Herbst et al. 1995, 1999). In addition to identification of ChHV5 in tumors, the virus has also been identified in tissues of apparently healthy turtles, possibly representing early or subclinical infection (Page-Karjian et al. 2012, 2015b). In wild sea turtle populations, viral shedding by infected turtles may represent a source of spontaneous infections in established turtle aggregations, and may be critical to sustaining viral transmission cycles, particularly in populations with shift- ing densities such as green turtles (Herbst et al. 2008, Breban et al. 2009). Although we now understand that many turtles infected with ChHV5 may live free of gross clinical signs (i.e. free of FP tumors), it is still unknown whether clinically normal turtles with molecular evidence of ChHV5 infection experience any concurrent health issues detectable via clinical diagnostic testing such as blood analysis (Page-Karjian et al. 2012). This may be especially applicable to nesting female sea turtles, since in other species, including humans, immunosuppression related to pregnancy/gravidity is a major factor in recrudescence of latent herpesvirus infections (Dahl et al. 1999).

Another herpesvirus known to infect green turtles in Florida is chelonid alphaherpesvirus 6 (ChHV6) (Davison 2010). This virus was implicated in an outbreak of respiratory and skin disease in maricultured juvenile green turtles, which presented with pneumonia and associated dyspnea, buoyancy abnormalities, conjunctivitis, and caseous keratitis that resulted in mortality of affected turtles within 2-3 wk of the appearance of clinical signs (Jacobson et al. 1986). Lesions associated with ChHV6 have never been reported in free-ranging green turtles; however, application of a serological assay developed to detect antibodies to ChHV6 demonstrated that $\sim 10-22 \%$ of free-ranging juvenile and sub-adult green turtles in Florida carry antibodies to ChHV6 (Coberley et al. 2001a,b).

Juno Beach, Florida is a relatively small stretch of beach $(9.62 \mathrm{~km})$, yet it hosts one of the largest aggregations of nesting green turtles in Florida and is one of the highest-density nesting beaches in the state (Fuentes et al. 2016, FWC 2018c, Sella \& Fuentes 2019). The green turtles that nest in this area are part of the Greater Caribbean green turtle management unit, within the Northwest Atlantic regional management unit, and likely comprise the northern extent of the southeastern Florida nesting population (Wallace et al. 2010, Shamblin et al. 2015). Consequently, monitoring sea turtle health on Juno Beach is critical to develop an up-to-date baseline reference index for sea turtle health in Florida, and in the Western Atlantic in general. Although this high-profile nesting green turtle population has been routinely monitored for nest counts since 1989, an in-depth health assessment of these turtles has not been previously conducted. Data resulting from such an assessment can be critical from an epidemiological standpoint, especially for use in developing mitigation plans for any future green turtle population 'crashes' or epizootics as have been documented in 
the past (FWC 2018b). Detailed health data from 'healthy' adult females that nest on Juno Beach is also needed as a reference baseline for adult green turtles admitted into rehabilitation facilities, as they frequently strand during the nesting season as a result of boat strikes, entanglements, and other nearshore hazards.

The objective of this study was to conduct a health assessment of adult female green turtles nesting on Juno Beach in order to (1) establish comprehensive baseline health indices, including physical examination findings, hematology, and plasma biochemistry values; (2) evaluate whole blood and plasma samples to identify individuals infected with enzootic herpesviruses (ChHV5, ChHV6); and (3) compare the measured health indices between the turtles that did versus those that did not test positive for either ChHV5 or ChHV6, to identify any blood biomarkers that may be associated with subclinical infection.

\section{MATERIALS AND METHODS}

\subsection{Study period, site, and subjects}

Nesting green turtles were encountered during nightly surveys of $9.62 \mathrm{~km}$ of sea turtle nesting beach from June to August 2017 in Juno Beach, Florida $\left(26^{\circ} 56^{\prime} 36^{\prime \prime} \mathrm{N}, 80^{\circ} 04^{\prime} 15^{\prime \prime} \mathrm{W}\right.$ ) (Fig. 1). Samples were collected across the season (June-August) as turtles were encountered. Individual turtles were identified by external flipper tags (metal 0.3 Inconel, National Band \& Tag) and/or internal passive integrated transponder (PIT) tags (Biomark $\left.{ }^{\circledR}\right)$; new tags were applied if they were not already present. The nests laid by these 60 turtles were subsequently monitored through incubation, hatching, and emergence.

\subsection{Sample collection}

To avoid any confounding effects of handling stress on plasma corticosterone concentrations, the turtles in this study were minimally handled prior to blood collection (Flower et al. 2015, Hunt et al. 2016). Blood samples $(10 \mathrm{ml})$ were aseptically collected from the external jugular vein (i.e. dorsal cervical sinus) of adult females during oviposition, once the turtle had laid a minimum of 50 eggs. Specifically, the venipuncture site was thoroughly swabbed with betadine and alcohol, and a $10 \mathrm{ml}$ blood sample was collected using a $10 \mathrm{ml}$ syringe (Covidien Monoject ${ }^{\mathrm{TM}}$, Sherwood Medical) fitted to a 20-gauge, 1.5 inch $(\sim 3.8 \mathrm{~cm})$ needle (Covidien Monoject $\left.{ }^{\mathrm{TM}}\right)$. Blood was then placed into $10 \mathrm{ml}$ BD lithium heparin Vacutainer ${ }^{\circledR}$ tubes (Becton-Dickinson), insulated, and chilled over ice packs. Direct contact of blood tubes with ice packs was avoided to prevent hemolysis. No restraint was required for the nesting turtles, although head placement was occasionally adjusted to obtain better positioning for blood sample acquisition. After blood collection, the venipuncture site was again disinfected with betadine. After sample collection, maximum curved carapace length (CCL) and curved carapace width (CCW) were measured using a nylon tape. Each turtle was given a physical examination, including visual assessment of: mentation and alertness (assessed after oviposition); body condition; shell epibiota coverage and composition; ambulation and movement of head, tail, and appendages; observation of any grossly visible fresh traumatic injuries, fishing gear entanglement/ingestion, developmental abnormalities, and/or FP tumors; and ability to properly complete the nesting fixed action pattern (e.g. creating a body pit, digging, depositing eggs, and covering the nest). While green turtles lay 2-8 clutches per nesting season (Esteban et al.

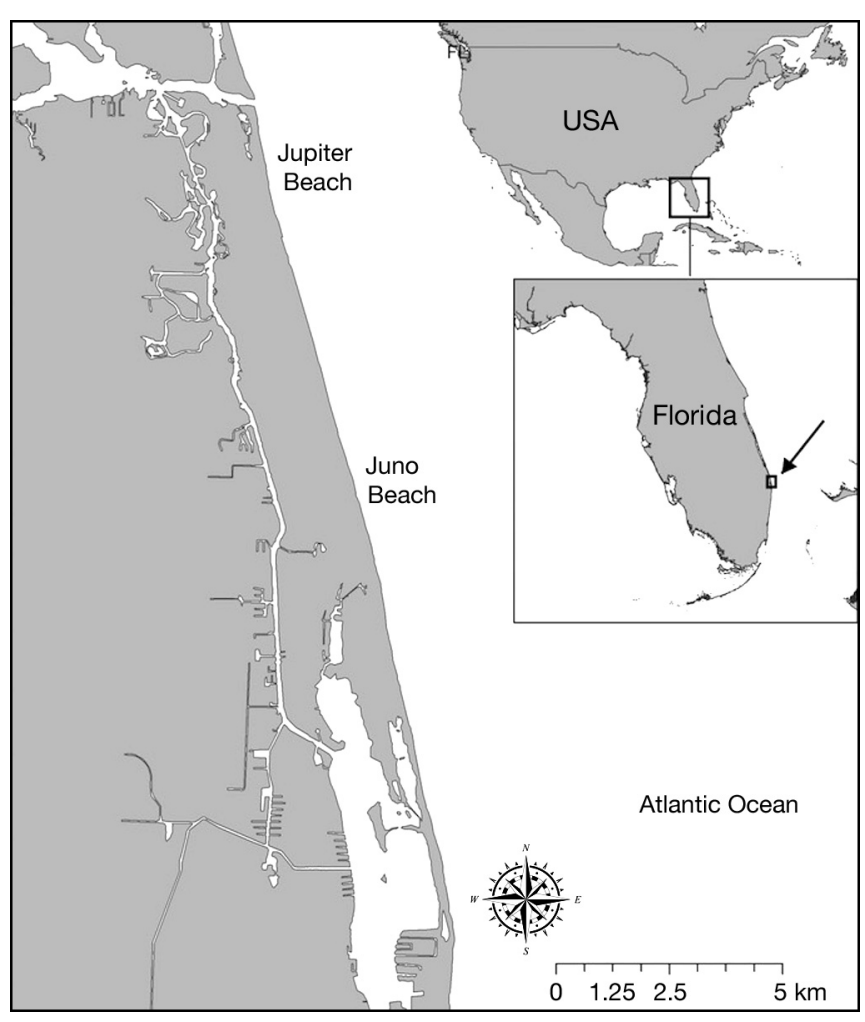

Fig. 1. Juno Beach, Florida, USA, hosts one of the largest aggregations of nesting green turtles in Florida and is one of the highest-density nesting beaches in Florida based on number of nesting turtles per square kilometer (image from Perrault et al. 2011) 
2017), due to logistical constraints, extended nest monitoring was limited to the clutches included in this study (one per adult female turtle).

Blood samples were processed at the Research Laboratory of the Loggerhead Marinelife Center, Juno Beach, FL; within 6-8 h of collection: 2 blood films were made on glass slides using well-mixed blood; one microhematocrit tube (FisherBrand ${ }^{\mathrm{TM}}$ ) was filled with whole blood and sealed with Hemato-Seal ${ }^{\mathrm{TM}}$ capillary tube sealant (FisherBrand ${ }^{\mathrm{TM}}$ ). The blood films were stained using modified Wright stain (Sigma Diagnostics ${ }^{\mathrm{TM}}$ ). Within $6-12 \mathrm{~h}$ of collection, the blood samples in the lithium heparin-coated tubes were centrifuged for $8 \mathrm{~min}$ at $\sim 4200 \times g(5000 \mathrm{rpm})$ using an LW Scientific C5 centrifuge. All plasma was collected and visually assessed to determine hemolysis score based on plasma color (0 [no hemolysis] = clear or pale yellow; 1+ [slight hemolysis $]=$ pinktinged; 2+ [moderate to marked hemolysis] = cherry red) (Adiga \& Yogish 2016, Stacy \& Innis 2017). Remaining plasma and whole blood samples were stored at $-80^{\circ} \mathrm{C}$ for $3-6$ mo prior to being thawed at room temperature for further analyses.

\subsection{Nest inventory}

Eggs hatched, and hatchlings emerged from the study nests during August-October 2017. Three days following a mass emergence event, nests were excavated and inventoried to determine hatching success and emergence success (after Miller 1999). Only yolked eggs were included in calculations of hatching success and emergence success. Any depredated, inundated, or washed out nests (due to storm) were noted and not included in statistical analyses.

Hatching success was calculated as: [no. hatched eggs]/[no. total eggs (hatched eggs + unhatched eggs + pipped + live pipped)], and emergence success was calculated as: [(no. hatched eggs) - (no. live hatchlings in nest + no. dead hatchlings)]/[no. total eggs (hatched eggs + unhatched eggs + pipped + live pipped)] (Miller 1999).

\subsection{Hematology and plasma biochemistry}

To determine packed cell volume (PCV), microhematocrit tubes were centrifuged for $8 \mathrm{~min}$ at $4200 \times g$ using an LW Scientific C5 centrifuge with microhematocrit tube inserts. A hematocrit microcapillary tube reader was used to interpret the PCV (\%). Blood film evaluation included white blood cell
(WBC) estimate, WBC differential (including heterophils, lymphocytes, monocytes, eosinophils, and basophils) based on 200 cell counts, and morphological evaluation of red blood cells (RBCs), WBCs, and thrombocytes. Immature heterophils were counted as a separate WBC category in addition to mature heterophils. Immature RBCs were quantified as no. of immature RBCs / 100 mature RBCs (Stacy et al. 2011). Plasma samples were analyzed for biochemistry variables, including plasma protein electrophoretic fractions. Biochemical analysis of plasma samples was conducted at the Loggerhead Marinelife Center by a trained technician using a dry slide biochemistry analyzer (IDEXX Catalyst $\mathrm{Dx}^{\mathrm{TM}}$ ). Biochemical analytes included alanine aminotransferase activity (ALT), albumin, alkaline phosphatase activity (ALP), aspartate aminotransferase activity (AST), calcium, chloride, cholesterol, globulins, glucose, phosphorus, potassium, sodium, and uric acid. Total solids in plasma were estimated using a Reichert ${ }^{\circledR}$ VET360 handheld refractometer. Hemoglobin in previously frozen, thawed whole blood was analyzed using a HemoCue ${ }^{\circledR} \mathrm{Hb} 201^{+}$photometer with HemoCue ${ }^{\circledR} \mathrm{Hb} 201$ microcuvettes and a measuring range of $0-256 \mathrm{~g} \mathrm{l}^{-1}$. This analyzer has been validated for use in birds (Velguth et al. 2010, Harter et al. 2015) and uses a modified azidemethemoglobin reaction.

Frozen plasma aliquots $(0.5-1.0 \mathrm{ml})$ were shipped overnight on dry ice to the University of Miami Avian \& Wildlife Laboratory (UMAW), where they were analyzed for haptoglobin concentration using the Daytona analyzer (Randox) and the Tridelta HP kit (Tridelta Diagnostics), and for protein fractions using the SPIFE 3000 system (Helena Laboratories) and accompanying gels (Dickey et al. 2014). Fraction delimits were placed using the following conventions: pre-albumin, albumin, alpha ${ }_{1-}$, alpha ${ }_{2-}$, beta-, and gamma-globulins. Total protein was quantified using the Biuret method at UMAW. The albumin: globulin $(\mathrm{A}: \mathrm{G})$ ratio was calculated.

\subsection{Immune function, oxidative stress, and physiological stress}

Lysozyme activity of plasma samples was measured using modifications of standard turbidity assays performed by Keller et al. (2006); detailed methodology provided in the Supplement at www.int-res. com/articles/suppl/n042p021_supp.pdf. Presence of reactive oxygen species (ROS) and reactive nitrogen species (RNS) in plasma samples was evaluated using an OxiSelect ${ }^{\mathrm{TM}}$ In Vitro ROS/RNS Assay Kit 
(Green Fluorescence, Cell Biolabs). In this assay, a reduced fluorophore is oxidized to a fluorescent molecule $(20,70$-dichlorodihydrofluorescein [DCF]) in the presence of ROS and RNS. This microplate-based assay provides a measurement of total free radical population within a sample, determined using a DCF standard curve. Total superoxide dismutase (SOD), catalase (Cayman Chemical), and total glutathione (Enzo Life Sciences) activities were measured in plasma (SOD) and erythrocyte pellet (catalase and total glutathione) samples using commercially available assay kits and following the manufacturers' instructions. Fluorescence was measured on a BioTek ${ }^{\circledR}$ ELX800 microplate reader at $480 \mathrm{~nm}$ excitation and $530 \mathrm{~nm}$ emission for ROS/RNS, and at 440-470 nm for SOD, catalase, and total glutathione.

Frozen plasma aliquots were shipped on dry ice to Southeastern Louisiana University, where corticosterone assays were performed. A commercially available enzyme-linked immunosorbent assay (ELISA; Enzo Life Sciences) was used to determine plasma corticosterone concentrations (Valverde et al. 1999). Plates were read at $450 \mathrm{~nm}$ in a microplate reader (Bio-Rad Model 680). Absorbance data were analyzed with a 4parameter logistic equation after correcting for blanks. Inter-assay variation was $11.8 \%$, and mean intraassay variation was $9.5 \%$. Any samples outside of the range 20-80\% were assayed again (Clarkson 2016).

\subsection{Molecular diagnostics for ChHV5 and ChHV6 DNA}

Genomic DNA (gDNA) was extracted from thawed whole blood samples using the DNeasy Blood \& Tissue kit according to the manufacturer's instructions (Qiagen). Using a NanoDrop 2000c (Thermo Scientific ${ }^{\mathrm{TM}}$ ), concentrations of extracted gDNA samples were quantified (units: $\mu \mathrm{g} \mathrm{\mu l}^{-1}$ ), and gDNA purity was assessed using the ratio of absorbance at 260 and $280 \mathrm{~nm}$, with acceptance criteria of ratios of $\sim 1.8-2.0$ (NanoDrop 2007). Extracted DNA samples were assessed for the presence of the ChHV5 UL30 gene segment using a singleplex, probebased quantitative PCR (qPCR) and the methodologies outlined by Page-Karjian et al. (2015b). qPCR reactions were conducted using an AriaMx Real-Time PCR System (Agilent), and qPCR data were analyzed with AriaMX software (Agilent, Version 1.3).

A 1794 bp clone of the ChHV6 DNA polymerase (UL30) gene (clone LETHV 221, GenBank accession number EU006876.1) was used to design a primers/ dual-labeled (6-FAM/BHQ1) probe set to detect a unique 112 bp ChHV6 DNA amplicon in submitted samples. Submitted samples were tested with the qPCR assay (Infectious Disease Laboratory at the University of Georgia, USA) using standard operating procedures and controls for the assay. Detailed methods are described in the Supplement.

\subsection{ELISA detection of antibodies to ChHV5 and ChHV6 peptides}

Separated plasma samples were analyzed for antibodies to ChHV5 and ChHV6 peptides at the University of Georgia Infectious Disease Laboratory in Athens, Georgia. To evaluate for infection by ChHV5 and ChHV6 in a turtle's immunologically detectable past, samples were analyzed in triplicate using ELISAs that test for antibodies to ChHV5 and ChHV6 purified synthetic peptide antigens. Both ELISA assays were developed and validated based on modifications of previously published protocols for ChHV5 and ChHV6 assays (Coberley et al. 2001a, Herbst et al. 2008) and were performed using the laboratory's standard operating procedures with negative and positive control sera. Detailed methods are provided in the Supplement.

\subsection{Statistical analyses}

Means \pm standard deviation (SD) were calculated for morphological (CCL, CCW) and qPCR data for all turtles. Blood health reference intervals were determined for study turtles following the consensus guidelines set forth by the American Society for Veterinary Clinical Pathology (Friedrichs et al. 2012). Detailed methods for reference interval development are provided in the Supplement.

A multivariate framework was used to compare health parameters between turtles with positive and negative results for ChHV5 DNAemia (viral DNA circulating in the bloodstream) via $\mathrm{qPCR}$, between turtles with positive and negative results for ChHV5 exposure via ELISA, and between turtles with positive and negative results for ChHV5 via qPCR and ELISA (combined). Health parameters were also compared using an identical methodology for turtles that tested positive and negative for ChHV6 via ELISA. The qualitative level of agreement between the 2 assays (qPCR and ELISA) for ChHV5 and ChHV6 was determined using Cohen's kappa ( $\kappa)$ coefficient (Landis \& Koch 1977). After removing individuals with missing values for some blood analytes, 53 turtles were included in a correlation analy- 
sis of 8 selected blood health parameters (alpha- and gamma-globulins, albumin, heterophils, lymphocytes, glucose, ROS/RNS, and total glutathione). Alpha $_{1}$ - and alpha ${ }_{2}$-globulin concentrations were combined to generate a total alpha-globulin concentration. Correlations between these variables were visualized using the packages 'corrplot' (Murdoch \& Chow 1996, Friendly 2002) and 'ggplot2' (Wickham 2016) in R version 3.4.1 (R Core Team 2017). Because these variables did not meet the assumptions of multivariate normality or homogeneity of covariance, we used the nonparametric multivariate framework from the package 'npmv' (Burchette et al. 2017) in R to test for differences in 3 separate analyses, based on the 3 methods used to determine ChHV5 infection status (qPCR, ELISA, and at least 1 positive determined by either qPCR or ELISA), and 1 analysis to test for differences between ChHV6-positive and ChHV6negative turtles as determined by ELISA. We also performed a principal components analysis (PCA) using the 'stats' package (R Core Team 2017) to visualize blood analytes in a 2-dimensional setting for each comparison.

Using SPSS statistical software (v.25.0, IBM), Spearman's correlation coefficient analyses were used to evaluate the strength and direction of the relationships between haptoglobin concentration and plasma electrophoresis data, plasma hemolysis score (0-2), and whole blood hemoglobin concentration; and between plasma corticosterone concentration and physiological measurements indicative of stress (e.g. plasma glucose concentration, plasma lysozyme, SOD, ROS/RNS activities, lysed erythrocyte catalase and total glutathione activities, total estimated leukocyte count, heterophil count, and heterophil:lymphocyte ratio). Linear least-squares regressions were used to establish a conversion equation between PCV and hemoglobin concentration in whole blood.

Evidence suggests that green turtles are capital breeders (a life history strategy that involves relying on body reserves stored prior to reproduction and ceasing to feed during reproduction [Bjorndal 1985, 1997, Miller 1997]; therefore, linear least-squares regressions were used to determine if any blood analytes significantly decreased during the nesting season (independent variable = date of nesting encounter). Analytes evaluated include PCV and all hematology and plasma biochemistry analytes, as well as oxidative stress and antioxidant capacity analytes. Each individual analyte was explored for outliers using Tukey's method (Tukey 1977). Normality of the regression residuals was assessed using the
Shapiro-Wilk statistic. If the residuals were non-normal, square-root transformations were carried out. When residuals could not be normalized, Spearman's rank order correlations were performed on the variables of interest in relation to date of nesting.

\subsection{Ethics statement}

Sample and data collection and use were conducted by authorized personnel under Florida Fish and Wildlife Conservation Commission's Marine Turtle Permits 205 and 139. Sample use by A. PageKarjian was reviewed and approved by the Florida Atlantic University Institutional Animal Care and Use Committee under Animal Product Use protocol A(T)16-02.

\section{RESULTS}

\subsection{Nesting females}

A total of 4343 green turtle nests were documented on Juno Beach in 2017, which was the busiest nesting year on record for this $9.62 \mathrm{~km}$ stretch of beach. This equates to a nesting density of 452 nests $\mathrm{km}^{-1}$. Blood samples were collected from 60 green turtles that nested on Juno Beach during 2017; assuming that each individual turtle nests $~ 5-8$ times (Esteban et al. 2017 ), these 60 turtles represent $\sim 7-11 \%$ of all green turtles that nested on Juno Beach in 2017. In 2017, Juno Beach hosted $32.7 \%$ and $8.2 \%$ of all green turtle nests in Palm Beach County and Florida as a whole, respectively (FWC 2018a). Thus, extrapolated to the state of Florida, which had an estimated 6600-10632 nesting green turtles in 2017 (and assuming a clutch frequency of 5-8 nests), with this study we sampled $\sim 0.5-1 \%$ of the entire nesting green turtle population of Florida. For the 60 turtles sampled, the mean $( \pm \mathrm{SD}) \mathrm{CCL}$ was $104.4 \pm 5.8 \mathrm{~cm}$ (range: 90.0-114.4 cm), and the mean CCW was 95.2 $\pm 5.2 \mathrm{~cm}$ (range: $80.5-104.1 \mathrm{~cm}$ ).

Reproductive success data are only available for $28 / 60(46.7 \%)$ turtles, as 32/60 nests (53.3\%) were washed out during Hurricane Irma in September 2017. For those 28 nests, the mean total number of eggs was $120 \pm 22$ (range: 79-166), mean hatching success was $66.8 \pm 22.5 \%$ (range: $2.8-96.4 \%$ ), and mean emergence success was $54.7 \pm 24.2 \%$ (range: $0.7-92.7 \%$ ).

All turtles included in this study were determined to be in good or robust body condition based on gross 
observation of neck and shoulder fat thickness, had minimal shell epibiota, and had no observable evidence of human interaction (i.e. fishing gear entanglement/ingestion). No major developmental abnormalities, serious traumatic injuries, or external FP tumors were observed on any of the turtles. Mild physical abnormalities were observed on 44/60 (73.3\%) turtles (detailed in Table S1), and 21 turtles had more than 1 abnormality. Fresh scratches, indentations, and scars on the cranial carapace and/or shoulder(s) were interpreted to be 'mating scars', which are commonly observed on nesting sea turtles (Miller 1997). Small ( 0.5-3.0 cm diameter), smooth, moderately firm skin nodules were observed on the shoulder regions of 3 turtles, and 1 turtle had a soft tissue nodule on a front flipper. The smooth texture of these nodules and pigmentation continuous with normal skin were grossly most consistent with scar/ granulation tissue and not suggestive of FP lesions, although diagnostic biopsies of these nodules were not taken. Three turtles had a single deformed hind limb, and 3 had all or part of 1 hind limb missing without any overt fresh wounds. Of the 6 extra scutes seen in 5 turtles, 3 were vertebral, 2 were costal, and 1 was a marginal scute. One turtle had a large, healed defect on the left caudal carapace, interpreted to be an old shark bite wound. Another turtle had an indentation on the right caudal carapace. One turtle had a flipper tag site on the left front flipper that was thought to be infected due to the presence of a small, organized focus of actively inflamed and necrotic tissue surrounding and engulfing the tag site. These health abnormalities were mild or incidental and representative of actively nesting, clinically normal turtles and were not deemed to be life-threatening or debilitating in any way. All turtles included in this study successfully migrated and reproduced and were therefore healthy enough to do so. Indeed, the mild lesions observed here may be expected in a free-ranging marine reptile population that has recently migrated and is in active breeding season.

\subsection{Hematological, plasma biochemical, and plasma protein electrophoresis analytes}

Reference intervals (95\% RIs) and the related 90\% confidence intervals developed for the hematological and plasma biochemistry (including plasma protein electrophoresis) data from the 60 adult female nesting turtles are presented in Table 1. Linear leastsquares regressions demonstrated statistically significant declines in several blood analytes over the nesting season (Table S2), although the lower range values were still within reference intervals for nesting green turtles.

\subsection{Oxidative stress and antioxidant capacity}

Descriptive statistics including mean $( \pm \mathrm{SD})$, median, and range for plasma analytes that measure innate immune capacity (lysozyme activity), oxidative stress (catalase, total glutathione, and ROS/RNS activities), and physiologic stress (corticosterone concentration) are shown in Table S3. No statistically significant trends were seen in any of these analytes over the nesting season.

\subsection{Diagnostics for viral infection}

Although none of the 60 turtles evaluated had grossly visible FP tumors, blood samples of 5/60 $(8.3 \%)$ turtles tested positive for ChHV5 DNA via qPCR. DNA sequences resulting from all 5 samples matched to ChHV5 partial genome (GenBank accession number AY646888.1) with $\geq 99 \%$ identity. All 60 samples tested positive for the Chelonia mydas-actin reference gene segment, demonstrating the presence of amplifiable C. mydas DNA in the samples. The mean ChHV5 DNA copy number for the 5 qPCRpositive samples was $798 \pm 898$ SD (range $=68-2278$ ) viral copies ( $\mu \mathrm{g}$ DNA) ${ }^{-1}$. None of the blood samples from the 60 turtles tested positive for ChHV6 DNA via qPCR.

Because biochemical analyses were prioritized, only 41 of the blood samples yielded enough plasma volume to also allow us to run ELISAs to detect antibodies to ChHV5 and/or ChHV6. Twelve of 41 (29.3\%) samples were interpreted to be positive for antibodies to ChHV5 compared to controls. Combined, the qPCR and ELISA assays for ChHV5 indicated that a total of $17 / 60(28.3 \%)$ of the adult female green turtles tested positive for ChHV5 DNA or antibodies to a viral peptide. There was no overlap between turtles that tested positive for the ChHV5 qPCR and ELISA assays; however, only 2 of the 5 turtles that tested positive via qPCR had plasma samples available for ELISA. Six of the 41 plasma samples (14.6\%) tested positive for antibodies to ChHV6. There was no diagnostic assay agreement between the qPCR and ELISA assays for ChHV6. Four turtles (4/41, or 9.8\%) tested positive for antibodies to both ChHV5 and ChHV6.

Of the 4 turtles with small cutaneous nodules, 1 tested positive for ChHV5 antibodies via ELISA but 


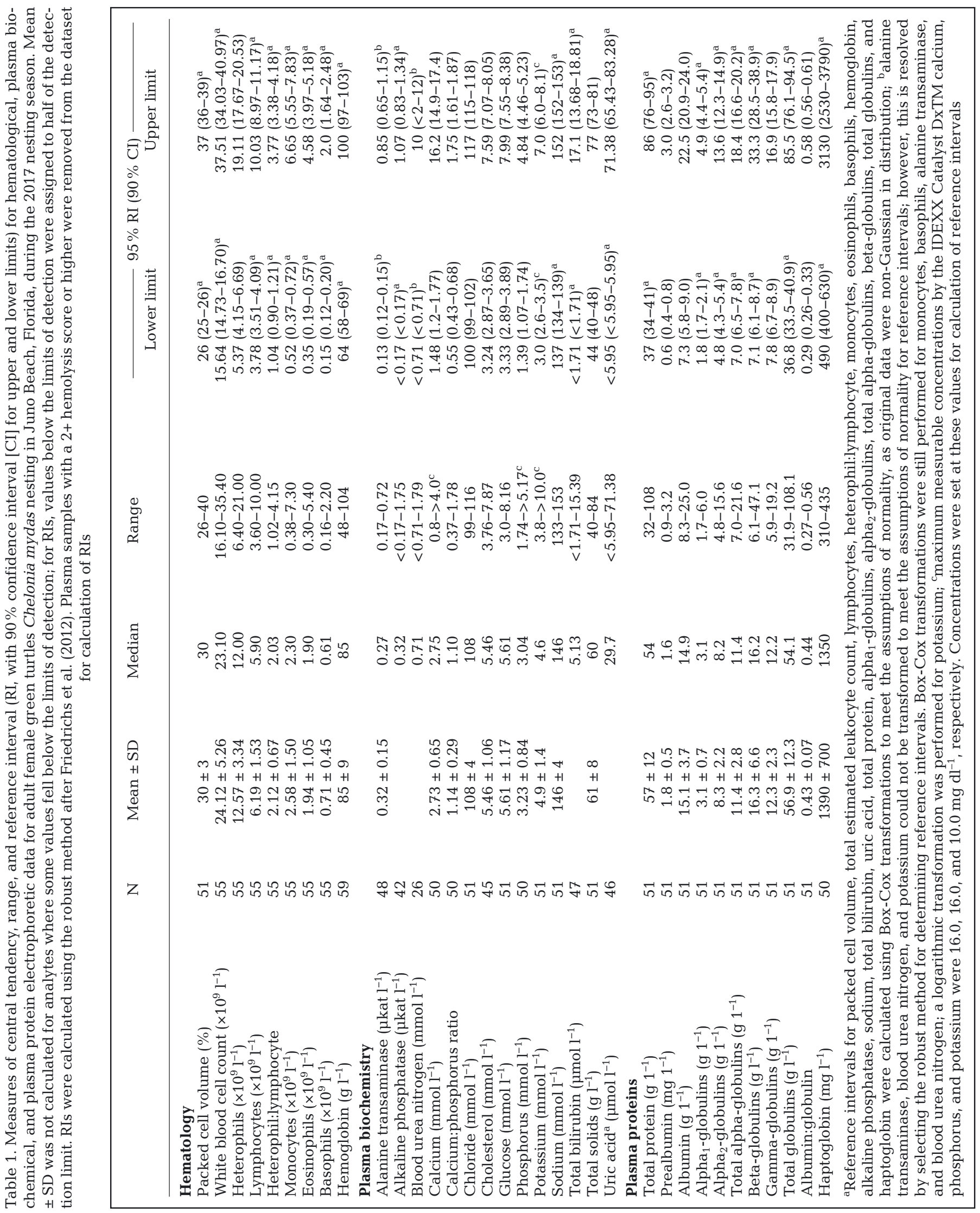


negative for ChHV5 via qPCR and negative for ChHV6; 1 tested negative for ChHV5 and ChHV6 via both qPCR and ELISA; and 2 tested negative for ChHV5 and ChHV6 via qPCR but did not have plasma samples available for serology.

\subsection{Correlations between health analytes}

Significant positive correlations were observed between plasma haptoglobin and total protein, albumin, beta-globulins, and total globulins, and a significant negative correlation was observed between plasma haptoglobin and the A:G ratio (Table S4). None of the correlation coefficients for the analyses between plasma corticosterone concentration and physiological measurements of stress (e.g. plasma glucose concentration, plasma lysozyme, SOD, ROS/RNS activities, lysed erythrocyte catalase and total glutathione activities, WBC count, heterophils, lymphocytes, and heterophil:lymphocyte ratio) were statistically significant (all had $\mathrm{p}>0.05$ ). Strong positive correlations were observed between albumin, alpha-globulins, and gamma-globulins. Strong negative correlations were found between gamma-globulins and lymphocytes, corticosterone, ROS/RNS, and total glutathione. Total glutathione was also negatively correlated with albumin and alpha-globulins. Correlation coefficients of 8 of these parameters are shown in Table 2. Linear regression analysis revealed a significant relationship $\left(r^{2}=0.47 ; \mathrm{p}<0.001\right)$ between hemoglobin concentrations from thawed whole blood and PCV, which can be described as: hemoglobin $\left[\mathrm{g} \mathrm{l}^{-1}\right]=(1.80 \times \mathrm{PCV})+31.18$.

Although we postulated that molecular evidence of herpesvirus exposure and/or recrudescence in nesting females may be associated with measurable immunological fluctuations, none of the 8 selected blood analytes (alpha- and gamma-globulin, albumin, heterophils, lymphocytes, glucose, ROS/RNS, and total glutathione) varied between turtles that did or did not test positive for ChHV5 DNA or antibodies via qPCR or serology, respectively. The 4 rank-based test statistics used to evaluate these data (ANOVA, Wilks' lambda, Lawley Hotelling, and Bartlett Nanda Pillai types) all had p-values $>0.05$. Similarly, these blood analytes did not significantly differ between ChHV6-positive and ChHV6-negative turtles. The PCA (Fig. 2) supports these results, with no visible segregation of ChHV5/ChHV6-positive and ChHV5/ ChHV6-negative turtles along any PC axes.

\section{DISCUSSION}

This study represents the most comprehensive health assessment data for a green turtle rookery worldwide to date, and as such provides a timely and useful profile of nesting female green turtle health for future comparative investigations. These data also represent a baseline profile for 'healthy' adult green turtles in Florida, to which health data from adult green turtles in rehabilitative care can be compared. We evaluated a broad suite of biological data, including measures of reproductive success, morphometrics, hematology, plasma chemistry, plasma protein fractions, haptoglobin, corticosterone, and measures of oxidative stress, antioxidative capacity, and innate immunity. We also tested for 2 herpesviruses of green turtles, ChHV5 and ChHV6, using detection techniques to differentiate between previous viral infection versus recent infection/reactivation, and evaluated the results alongside health analytes to understand whether either infection state was associated with detectable physiological changes. These comprehensive data allow critical insights into various aspects of physiology, biology, and herpesvirus epidemiology of a nesting green turtle population in southeastern Florida.

Table 2. Statistical correlations between 8 selected health analytes, ranging from -1 (perfectly negatively correlated), through 0 (no correlation), to 1 (perfectly positively correlated) in adult female green turtles Chelonia mydas nesting in Juno Beach, Florida. After removing individuals with some missing values, 53 turtles were included in this analysis. ${ }^{*}$ Denotes statistically significant correlations at $\mathrm{p}<0.05$. ROS (RNS): reactive oxygen (nitrogen) species

\begin{tabular}{|c|c|c|c|c|c|c|c|}
\hline & ROS/RNS & Lymphocytes & Heterophils & Alpha-globulins & Albumin & Gamma-globulins & Glucose \\
\hline Gamma-globulins & - & - & - & - & - & - & 0.10 \\
\hline Albumin & - & - & - & - & - & $0.67^{*}$ & 0.03 \\
\hline Alpha-globulins & - & - & - & - & $0.68^{*}$ & $0.68^{*}$ & 0.03 \\
\hline Heterophils & - & - & - & -0.14 & -0.06 & -0.07 & -0.04 \\
\hline Lymphocytes & - & - & $0.56^{*}$ & -0.11 & -0.01 & -0.23 & -0.04 \\
\hline ROS/RNS & - & 0.16 & -0.05 & -0.09 & -0.13 & -0.22 & -0.14 \\
\hline Total glutathione & -0.03 & -0.09 & -0.07 & -0.15 & -0.20 & $-0.30^{*}$ & -0.06 \\
\hline
\end{tabular}



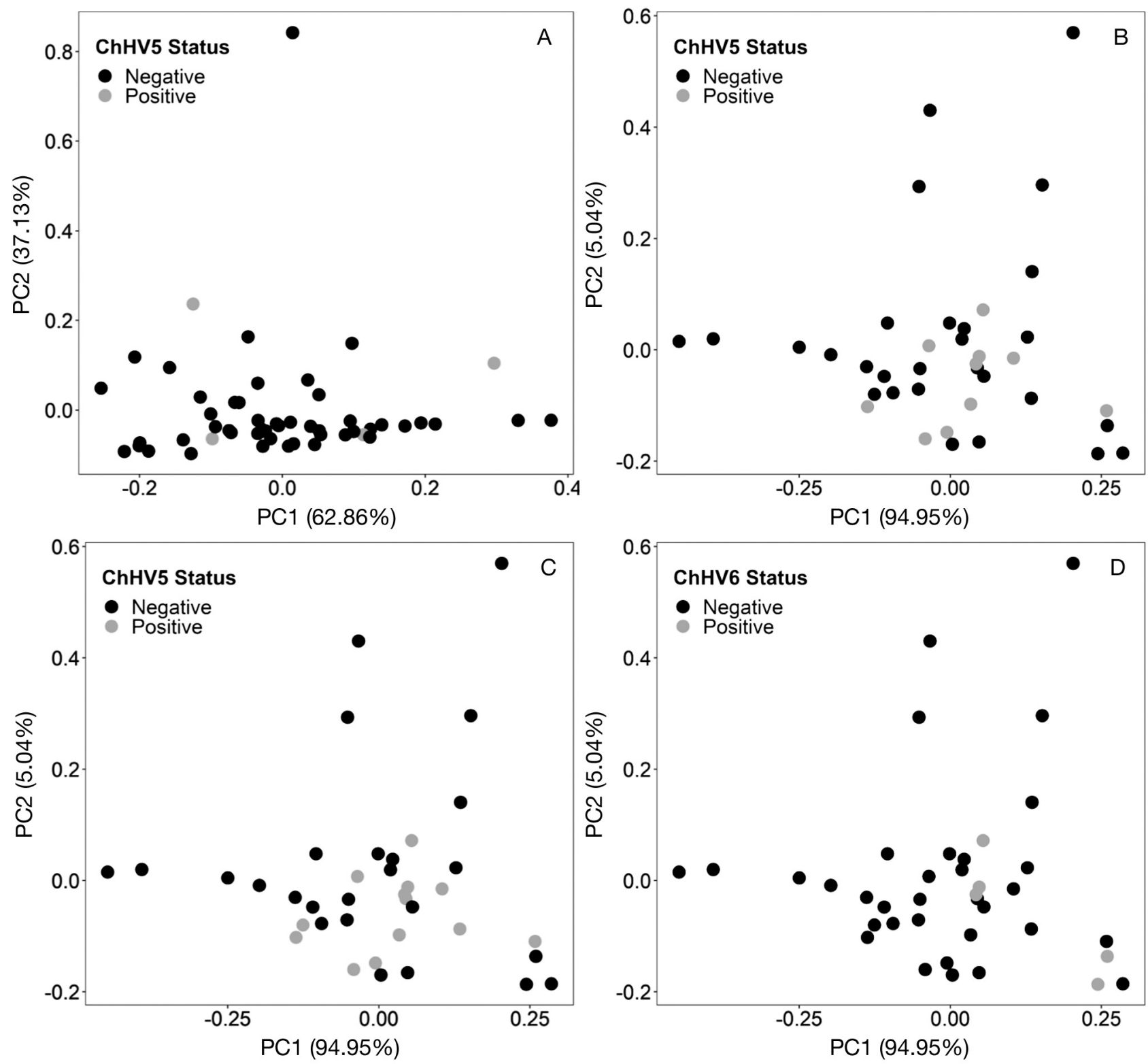

Fig. 2. Graphical representations of PCA including 8 blood analytes. Each point represents an individual animal's position within the PC axes, with color indicating that individual's infection status for (A) chelonid alphaherpesvirus 5 (ChHV5) as determined by qPCR, (B) ChHV5 as determined by ELISA, (C) ChHV5 as determined by a combination of qPCR and ELISA, in which an animal may be deemed positive if it tests positive using either method, and (D) ChHV6 as determined by ELISA

Although to date their foraging grounds are unknown from empirical observations, satellite-tagged adult female green turtles have been tracked from nesting beaches in eastern Florida to foraging grounds in the Florida Keys, and have been observed nesting in places as far away as Cuba (Moncada et al. 2019). Thus, the fitness of the turtles examined for this study is likely representative of the health of the ecosystems in which they forage and the oceanic corridors through which they migrate (Aguirre \& Lutz
2004), and these data can be extrapolated to better understand variables influencing sea turtle health in these locations.

\subsection{Plasma biochemistry}

The overall fitness of this group of turtles is further supported by the fact that the blood health reference intervals presented here fall within the ranges pre- 
sented for those analytes in this and other studies of healthy green turtles (Bolten \& Bjorndal 1992, Aguirre \& Balazs 2000, Flint et al. 2010, Osborne et al. 2010, Page-Karjian et al. 2015a), including reports of adult female green turtles (Hamann et al. 2006, Prieto-Torres et al. 2013). Many extrinsic and intrinsic factors can influence blood analyte data in sea turtles, including sex, age class, and life history stage; diet and body condition; pathogen, parasite, and toxin/toxicant exposure; environmental conditions and season; analytical methodologies; and various aspects of sample handling and processing, including the use of different anticoagulants (Bolten et al. 1992, Herbst \& Jacobson 2003, Hamann et al. 2006, Deem et al. 2009, Flint et al. 2010, Stacy \& Innis 2017). In circumstances wherein it may not be feasible to collect such an extensive data set as presented here, we recommend (minimally) assessing PCV, determining concentrations of plasma total solids (with a handheld refractometer) and glucose (with a handheld glucometer), and evaluating body condition, as low-cost, relatively easy-to-interpret analyses that can reliably infer the health status of nesting sea turtles (Perrault et al. 2016).

A significant positive relationship was observed between PCV and hemoglobin concentration in whole blood, and the mean $( \pm \mathrm{SD})$ coefficient of variation between measured hemoglobin (using the Hemocue ${ }^{\circledR}$ photometer) and the calculated hemoglobin concentration was $3.4 \pm 2.8 \%$. This indicates that PCV measurement is an accurate predictor of hemoglobin concentration in nesting green turtles.

The mean lysozyme activity data reported here overlap with lysozyme activity ranges reported in previous studies on foraging juvenile green turtles and Kemp's ridley turtles Lepidochelys kempii (Table S5), which in turn are notably lower than those reported for loggerhead sea turtles (e.g. Keller et al. 2006). These differences may be reflective of life history stage, differences in geographic regions, or the nutritional requirements of the different species. None of the innate immunity nor oxidative stress analytes significantly increased or decreased over the season, as seen for some of the other health analytes listed above, suggesting that circulating concentrations of these analytes are less influenced by decreased food and water intake during the nesting season than are other blood analytes (e.g. plasma proteins, electrolytes). Overall, the mean corticosterone concentrations reported here are within the normal range of values reported in other studies of nesting female green turtles (Table S5; Hamann et al. 2002, Al-Habsi et al. 2006, Ikonomopoulou et al. 2014).

\subsection{Physiological evidence of capital breeding}

Green turtles are capital breeders (Bjorndal 1985, 1997, Miller 1997), although opportunistic and/or supplemental foraging likely do occur during the nesting season (Hochscheid et al. 1999, Tucker \& Read 2001). We did not monitor all nesting events for the study turtles, and no turtles were recaptured/ resampled for this study. Nonetheless, the data presented here provide additional evidence of capital breeding and a catabolic state in nesting green turtles, since statistically significant declines were observed for biochemical (phosphorus) and plasma protein analytes (total solids, total protein, albumin, alpha $_{1^{-},}$alpha ${ }_{2-}^{-}$, and total globulins, A:G ratio) as the nesting season progressed. Declines in these variables from June to August ranged from 13-37\%, indicating decreased intestinal absorption of phosphorus and proteins, decreased protein synthesis, and/or increased protein catabolism. Calcium:phosphorus ratios significantly increased due to decreasing phosphorus concentration. Additionally, statistically significant increases were observed in plasma sodium, chloride, and pre-albumin concentrations, likely due to shifts in hydration status (Price et al. 2019). Thus, the data point to a decreasing nutritional status over time as the fasting turtles progressively mobilize and catabolize first lipid, then protein stores (Perrault et al. 2014).

\subsection{Diagnostic assays for ChHV5 and ChHV6 demonstrate alphaherpesvirus enzooticity}

This is the first study to report molecular evidence of herpesvirus infection in adult female green turtles. Detection of ChHV5 DNA in blood samples is interpreted to be a proxy for systemic viral DNAemia (viral DNA circulating in the bloodstream). The prevalence of turtles with blood samples that test positive for ChHV5 DNA is expected to be lower than the actual number of infected turtles, considering that most herpesviruses have a latent stage that is not expected to correlate to viral DNAemia, and to date the target cell type(s) for ChHV5 latency remain unknown (Page-Karjian et al. 2015b, 2017). A previous qPCR-based study suggested that in live turtles without FP, whole blood provided the best diagnostic sensitivity, followed by skin, urine, cloacal swabs, and plasma (Page-Karjian et al. 2015b). For the 5 turtles that tested positive for ChHV5 via $\mathrm{qPCR}$, the mean viral copy number (798 \pm 898 viral copies [ $\mu \mathrm{g}$ DNA $]^{-1}$; range $=68-2278$ ) was low compared to viral 
copy numbers typical of cutaneous FP tumors using the same qPCR assay, which generally range from thousands to millions $\left(1.6 \times 10^{3}-2.0 \times 10^{9}\right)$, but similar to ChHV5 DNA copy numbers previously reported for whole blood samples taken from juvenile green turtles with $\left(1.8 \times 10^{2}-3.9 \times 10^{3}\right)$ and without $(3.3 \times$ $10^{2}-2.8 \times 10^{4}$ ) external FP (Page-Karjian et al. 2015b). Compared to PCR, serology is thought to be a more sensitive way to detect previous viral infection and associated immune responses in a population, since it can identify individuals that have been infected in their immunologically detectably past, irrespective of their current state of viral replication and resulting nucleic acids or antigens (Page-Karjian \& Herbst 2017). The lack of overlap between the ELISA and PCR assay results reported here is likely because they test for 2 different infection states: viral DNAemia (PCR) versus previous infection (antibody ELISA). PCR and serology thus each provide incomplete information about the status of herpesvirus infection, and should be applied in tandem to give the most comprehensive diagnostic approach available to date for diagnosing current and/or previous ChHV5/ChHV6 infection. Furthermore, pairing serology with qPCR testing provides a way to discern previously infected individuals from those with a recrudescent infection (Dahl et al. 1999). Additional research is warranted to better understand the relationship between qPCR and serology data for ChHV5 and ChHV6.

High ChHV5 antibody seroprevalence ( $80 \%)$ was previously found among juvenile and sub-adult green turtles in 3 eastern central Florida sites in which a range (0-61.8\%) of FP prevalence data was recorded (Herbst et al. 2008). This apparent age difference in virus infection prevalence may be attributable to turtles infected as juveniles dying from the disease and therefore never reaching adulthood. Alternatively, if they recover from infection as juveniles, their virus-specific antibody titers may decline with age as circulating antibodies decrease over time post-infection. Statistical modeling of long-term capture data suggests that tumor regression and gradual recovery from FP disease in free-ranging green turtles are more common than previously believed (Patrício et al. 2016).

Antibodies to ChHV6 were observed in $14.6 \%$ of the turtles tested, suggesting infection by this virus at some point in their lifetime. This is similar to previous studies that reported 10-22\% ChHV6 seroprevalence in free-ranging juvenile green turtles in Florida (Coberley et al. 2001a,b). Our study is the first to report survey data testing for ChHV6 DNA in sea tur- tle whole blood. Four turtles in our study showed antibody reactivity to both ChHV6 and ChHV5, suggesting that $\sim 10 \%$ were infected by both viruses in their lives. This co-reactivity has been shown previously (Coberley et al. 2001a, Herbst et al. 2008). The ChHV5 and ChHV6 assays do not cross-react, and the $\mathrm{gH}$ peptide target antigens used in this study were similar to those used in a previous study in which cross-reactivity between the ChHV5 and ChHV6 assays was also ruled out (Herbst et al. 2008).

Notably, turtles with a current ChHV5 infection or previously infected by ChHV5/ChHV6 were indistinguishable from healthy turtles. This is important because we hypothesized that immunosuppression during migration and nesting could be a factor associated with herpesviral recrudescence in previously infected turtles. FP, the disease linked to ChHV5 infection, is rarely seen in nesting sea turtles, with low prevalence reported in some nesting aggregations (Cornelius \& Robinson 1983, Aguirre et al. 1999). During the 2017 sea turtle nesting season in Juno Beach, mild external FP disease was only observed in 1 adult female green turtle, although the turtle was not included in this study due to logistical reasons, and only a fraction $(<15 \%)$ of the turtles nesting there that year were closely examined for external FP tumors. The data presented here indicate that despite this apparent lack of clinical signs of disease, ChHV5 is enzootic in this green turtle rookery, characterized by an $8.3 \%$ prevalence of turtles with evidence of ChHV5 DNAemia, and a $29.3 \%$ prevalence of turtles with antibodies to ChHV5. Enzootic disease results when the force of infection is high enough that acquisition of protective immunity occurs in the majority of the population at a relatively young age, thereby reducing the disease prevalence in older age classes (Hay 2001).

\subsection{Conclusions}

Population viability is inseparable from the health of the individuals that constitute a given population; thus, effective conservation measures cannot take place unless the animals we are trying to protect are healthy (Karesh \& Cook 1995). Temporal and spatial studies of biology, physiology, and overall health in both free-ranging and captive populations are critical for supporting large-scale efforts to promote sea turtle population recovery. With this study, we provide fundamental baseline insights into the health status of nesting green turtles on the east central coast of Florida, including demonstration of herpes- 
virus enzooticity, that can be used as a reference for future efforts to assess the health status of an individual or population of green turtles. As anthropogenic activities continue to impact sea turtle population recovery, these comprehensive baseline data will provide a valuable resource for evaluating the impacts of various stressors (e.g. habitat degradation) on the population over time and will help inform wildlife and environmental policy management.

Acknowledgements. This work was supported by grants from the Sea Turtle Conservancy Florida Sea Turtle License Plate Grants Program (17-036R); the American Association of Zoo Veterinarians' Wild Animal Health Fund; and the Florida Save Our Seas Specialty License Plate Fund (administered by the Harbor Branch Oceanographic Institute Foundation). Thanks to Meghan Koperski of the Florida Fish and Wildlife Conservation Commission for help with permits, and to Sam Kiefer for help collecting samples and data. We also thank the staff and volunteers of Loggerhead Marinelife Center for assistance with nest monitoring and excavations, and the University of Miami Avian \& Wildlife Laboratory for technical assistance with sample analysis.

\section{LITERATURE CITED}

Adiga U, Yogish S (2016) Hemolytic index - a tool to measure hemolysis in vitro. J Biotechnol Biochem 2:49-52

Aguirre AA, Balazs GH (2000) Blood biochemistry values in green sea turtles, Chelonia mydas, with and without fibropapillomatosis. Comp Haematol Int 10:132-137

Aguirre AA, Lutz PL (2004) Marine turtles as sentinels of ecosystem health: Is fibropapillomatosis an indicator? EcoHealth 1:275-283

Aguirre AA, Spraker TR, Chaves A, Du Toit L, Eure W, Balazs GH (1999) Pathology of fibropapillomatosis in olive ridley turtles Lepidochelys olivacea nesting in Costa Rica. J Aquat Anim Health 11:283-289

Al-Habsi AA, Alkindi AYA, Mahmoud IY, Owens DW, Khan $\mathrm{T}$, al-Abri A (2006) Plasma hormone levels in the green turtles Chelonia mydas during peak period of nesting at Ras Al-Hadd-Oman. J Endocrinol 191:9-14

Bjorndal KA (1985) Nutritional ecology of sea turtles. Copeia 1985:736-751

Bjorndal KA (1997) Foraging ecology and nutrition of sea turtles. In: Lutz PL, Musick JA (eds) The biology of sea turtles. CRC Press, Boca Raton, FL, p 199-231

Bolten AB, Bjorndal KA (1992) Blood profiles for a wild population of green turtles (Chelonia mydas) in the southern Bahamas: size-specific and sex-specific relationships. J Wildl Dis 28:407-413

Bolten AB, Jacobson ER, Bjorndal KA (1992) Effects of anticoagulant and autoanalyzer on blood biochemical values of loggerhead sea turtles (Caretta caretta). Am J Vet Res 53:2224-2227

Breban R, Drake JM, Stallknecht DE, Rohani P (2009) The role of environmental transmission in recurrent avian influenza epidemics. PLOS Comput Biol 5:e1000346

Burchette WW, Ellis AR, Harrar SW, Bathke AC (2017) Nonparametric inference for multivariate data: the $\mathrm{R}$ package npmv. J Stat Softw 76:1-18
Cárdenas DM, Cucalón RV, Medina-Magües LG, Jones K, Alemán RA, Alfaro-Núñez A, Cárdenas WB (2019) Fibropapillomatosis in a green sea turtle (Chelonia mydas) from the southeastern Pacific. J Wildl Dis 55:169-173

Cazabon-Mannette M, Phillips ACN (2017) Occurrence of fibropapilloma tumours on green sea turtles Chelonia mydas in Trinidad, West Indies. Living World, J Trinidad Tobago Field Nat Club 2017:14-20

Clarkson PM (2016) Corticosterone and testosterone in two populations of immature Kemp's ridley sea turtles, Lepidochelys kempii, in the Gulf of Mexico. MSc thesis, Southeastern Louisiana University, Hammond, LA

Coberley SS, Herbst LH, Brown DR, Ehrhart LM and others (2001a) Detection of antibodies to a disease-associated herpesvirus of the green turtle, Chelonia mydas. J Clin Microbiol 39:3572-3577

* Coberley SS, Herbst LH, Ehrhart LM, Bagley DA, Hirama S, Jacobson ER, Klein PA (2001b) Survey of Florida green turtles for exposure to a disease-associated herpesvirus. Dis Aquat Org 47:159-167

Cornelius SE, Robinson DC (1983) Abundance, distribution, and movements of olive ridley sea turtles in Costa Rica, III. Endangered Species Report 13. U.S. Fish and Wildlife Service, Albuquerque, NM

* Dahl H, Fjaertoft G, Norsted T, Wang FZ, Mousavi-Jazi M, Linde A (1999) Reactivation of human herpesvirus 6 during pregnancy. J Infect Dis 180:2035-2038

* Davison AJ (2010) Herpesvirus systematics. Vet Microbiol 143:52-69

* Deem SL, Norton TM, Mitchell M, Segars A and others (2009) Comparison of blood values in foraging, nesting, and stranded loggerhead turtles (Caretta caretta) along the east coast of Georgia, USA. J Wildl Dis 45:41-56

* Dickey M, Cray C, Norton TM, Murray M and others (2014) Assessment of hemoglobin binding protein in loggerhead sea turtles (Caretta caretta) undergoing rehabilitation. J Zoo Wildl Med 45:700-703

Ene A, Su M, Lemaire S, Rose C and others (2005) Distribution of CFPHV variants in Florida: molecular genetic evidence for infection following recruitment to neritic developmental habitats. J Wildl Dis 41:489-497

Esteban N, Mortimer JA, Hays GC (2017) How numbers of nesting sea turtles can be overestimated by nearly a factor of two. Proc R Soc B 284:20162581

KFlint M, Morton JM, Limpus CJ, Patterson-Kane JC, Murray PJ, Mills PC (2010) Development and application of biochemical and haematological reference intervals to identify unhealthy green sea turtles (Chelonia mydas). Vet J 185:299-304

Flower JE, Norton TM, Andrews KM, Nelson SE, Parker CE, Romero LM, Mitchell MA (2015) Baseline plasma corticosterone, haematological and biochemical results in nesting and rehabilitating loggerhead sea turtles (Caretta caretta). Conserv Physiol 3:cov003

Foley AM (2016) Characteristics of green turtle fibropapillomatosis in the Northwest Atlantic as indicated by strandings. In: Hargrove S, Work T, Brunson S, Foley AM, Balazs G (comps) Proc 2015 International Summit on Fibropapillomatosis: Global Status, Trends, and Population Impacts. NOAA-TM-NMFS-PIFSC 54. U.S. Department of Commerce, National Oceanographic and Atmospheric Association, National Marine Fisheries Service, Honolulu, HI, p 12-14

Friedrichs KR, Harr KE, Freeman KP, Sladovitz B, Walton RM, Barnhart KF, Blanco-Chavez J (2012) American Col- 
lege of Veterinary Pathology reference interval guidelines: determination of de novo reference intervals in veterinary species and other related topics. Vet Clin Pathol 41:441-453

Friendly M (2002) Corrgrams: exploratory displays for correlation matrices. Am Stat 56:316-324

Fuentes MMPB, Gredzens C, Bateman BL, Boettcher R and others (2016) Conservation hotspots for marine turtle nesting in the United States based on coastal development. Ecol Appl 26:2708-2719

FWC (Florida Fish and Wildlife Conservation Commission) (2018a) Florida Index Nesting Beach Survey. http:// myfwc.com/research/wildlife/sea-turtles/nesting/beachsurvey-totals/ (accessed 9 June 2018)

FWC (2018b) Threats to sea turtles. http://myfwc.com/ research/wildlife/sea-turtles/threats/ (accessed 9 June 2018)

FWC (2018c) Statewide atlas of sea turtle nesting occurrence and density. http://myfwc.com/research/wildlife/ sea-turtles/nesting/nesting-atlas/(accessed 9 June 2018)

Hamann M, Jessop TS, Limpus CJ, Whittier JM (2002) Interactions among endocrinology, seasonal reproductive cycles and the nesting biology of the female green sea turtle. Mar Biol 140:823-830

Hamann M, Schäuble CS, Simon T, Evans S (2006) Demographic and health parameters of green sea turtles Chelonia mydas foraging in the Gulf of Carpentaria, Australia. Endang Species Res 2:81-88

Hamann M, Godfrey MH, Seminoff JA, Arthur K and others (2010) Global research priorities for sea turtles: informing management and conservation in the $21^{\text {st }}$ century. Endang Species Res 11:245-269

Harter TS, Reichert M, Brauner CJ, Milsom WK (2015) Validation of the i-STAT and HemoCue systems for the analysis of blood parameters in the bar-headed goose, Anser indicus. Conserv Physiol 3:cov021

Hay SI (2001) The paradox of endemic stability. Trends Parasitol 17:310

Herbst LH, Jacobson ER (2003) Practical approaches to studying sea turtle health and disease. In: Lutz P, Musick JA, Wyneken J (eds) The biology of sea turtles, Vol II. CRC Press, Boca Raton, FL, p 385-410

Herbst LH, Jacobson ER, Moretti R, Brown T, Sundberg JP, Klein PA (1995) Experimental transmission of green turtle fibropapillomatosis using cell-free tumor extracts. Dis Aquat Org 22:1-12

Herbst LH, Jacobson ER, Klein PA, Balazs GH, Moretti R, Brown T, Sundberg JP (1999) Comparative pathology and pathogenesis of spontaneous and experimentally induced fibropapillomas of green turtles (Chelonia mydas). Vet Pathol 36:551-564

Herbst LH, Lemaire S, Ene AR, Heslin DJ and others (2008) Use of baculovirus-expressed glycoprotein $\mathrm{H}$ in an enzyme-linked immunosorbent assay developed to assess exposure to chelonid fibropapillomatosis-associated herpesvirus and its relationship to the prevalence of fibropapillomatosis in sea turtles. Clin Vaccine Immunol 15:843-851

Hochscheid S, Godley BJ, Broderick AC, Wilson RP (1999) Reptilian diving: highly variable dive patterns in the green turtle Chelonia mydas. Mar Ecol Prog Ser 185:101-112

Hunt KE, Innis C, Kennedy AE, McNally KL, Merigo C (2016) Assessment of ground transportation stress in juvenile Kemp's ridley sea turtles (Lepidochelys kempii). Conserv Physiol 4:cov071
Ikonomopoulou MP, Bradley AJ, Ibrahim K, Limpus CJ, Fernandez-Rojo MA, Vagenas D, Whittier JM (2014) Hormone and metabolite profiles in nesting green and flatback turtles: turtle species with different life histories. Adv Zool 2014:503209

Jacobson ER, Gaskin JM, Roelke M, Greiner EC, Allen J (1986) Conjunctivitis, tracheitis, and pneumonia associated with herpesvirus infection in green sea turtles. J Am Vet Med Assoc 189:1020-1023

Jones K, Ariel E, Burgess G, Read M (2016) A review of fibropapillomatosis in green turtles (Chelonia mydas). Vet J 212:48-57

Karesh WB, Cook RA (1995) Applications of veterinary medicine to in situ conservation efforts. J Zoo Wildl Med 26: 2-9

Keller JM, McClellan-Green PD, Kucklick JR, Keil DE, Peden-Adams MM (2006) Effects of organochlorine contaminants on loggerhead sea turtle immunity: comparison of a correlative field study and in vitro exposure experiments. Environ Health Perspect 114:70-76

KLackovich JK, Brown DR, Homer BL, Garber RL and others (1999) Association of herpesvirus with fibropapillomatosis in the green turtle Chelonia mydas and the loggerhead turtle Caretta caretta in Florida. Dis Aquat Org 37: 89-97

Landis JR, Koch GG (1977) The measurement of observer agreement for categorical data. Biometrics 33:159-174

Miller JD (1997) Reproduction in sea turtles. In: Lutz PL, Musick JA (eds) The biology of sea turtles. CRC Press, Boca Raton, FL, p 51-81

Miller JD (1999) Determining clutch size and hatching success. In: Eckert KL, Bjorndal KA, Abreu-Grobois FA, Donnelly M (eds) Research and management techniques for the conservation of sea turtles. IUCN/SSC Marine Turtle Specialist Group Publication No. 4. IUCN, Washington, DC

Moncada F, Coppenrath CM, Hirsch S, Nodarse G, PageKarjian A, Reeves AM, Perrault JR (2019) Nesting green turtle tagged in Cuba, recaptured in Florida. Mar Turtle Newsl 156:1-2

Murdoch DJ, Chow ED (1996) A graphical display of large correlation matrices. Am Stat 50:178-180

NanoDrop (2007) 260/280 and 260/230 Ratios. NanoDrop ${ }^{\circledR}$ Technical Support Bulletin T009. NanoDrop ${ }^{\circledR}$ Technologies, Inc., Wilmington, DE

Kosborne AG, Jacobson ER, Bresette MJ, Singewald DA, Scarpino RA, Bolten AB (2010) Reference intervals and relationships between health status, carapace length, body mass, and water temperature and concentrations of plasma total protein and protein electrophoretogram fractions in Atlantic loggerhead sea turtles and green turtles. J Am Vet Med Assoc 237:561-567

Page-Karjian A, Herbst LH (2017) Viruses. In: Manire CA, Norton TM, Stacy BA, Innis CJ, Harms CA (eds) Sea turtle health and rehabilitation. J. Ross Publishing, Plantation, FL, p 730-785

* Page-Karjian A, Torres F, Zhang J, Rivera S and others (2012) Presence of chelonid fibropapilloma-associated herpesvirus in tumored and non-tumored green turtles, as detected by polymerase chain reaction, in endemic and nonendemic aggregations, Puerto Rico. Springerplus 1:35

* Page-Karjian A, Rivera S, Torres F, Diez C, Moore D, Van Dam R, Brown C (2015a) Baseline blood values for healthy free-ranging green sea turtles (Chelonia mydas) in Puerto Rico. Comp Clin Pathol 24:567-573 
Page-Karjian A, Norton TM, Ritchie B, Brown C, Mancia C, Jackwood M, Gottdenker NL (2015b) Quantifying chelonid herpesvirus 5 in symptomatic and asymptomatic rehabilitating green sea turtles. Endang Species Res 28: 135-146

Page-Karjian A, Gottdenker NL, Whitfield J, Herbst L, Norton TM, Ritchie B (2017) Potential non-cutaneous sites of chelonid herpesvirus 5 persistence and shedding in green turtles (Chelonia mydas). J Aquat Anim Health 29: 136-142

Patrício AR, Diez CE, van Dam RP, Godley BJ (2016) Novel insights into the dynamics of green turtle fibropapillomatosis. Mar Ecol Prog Ser 547:247-255

Perrault JR, Wyneken J, Thompson LJ, Johnson C, Miller DL (2011) Why are hatching and emergence success low? Mercury and selenium concentrations in nesting leatherback sea turtles (Dermochelys coriacea) and their young in Florida. Mar Pollut Bull 62:1671-1682

Perrault JR, Wyneken J, Page-Karjian A, Merrill A, Miller D (2014) Seasonal trends in nesting leatherback turtle (Dermochelys coriacea) serum proteins further verify capital breeding hypothesis. Conserv Physiol 2: cou002

Perrault JR, Page-Karjian A, Miller DL (2016) Nesting leatherback sea turtle (Dermochelys coriacea) packed cell volumes indicate decreased foraging during reproduction. Mar Biol 163:232

Price ER, Sotherland PR, Wallace BP, Spotila JR, Dzialowski EM (2019) Physiological determinants of the internesting interval in sea turtles: a novel 'water-limitation' hypothesis. Biol Lett 15:20190248

Prieto-Torres DA, Hernandez JL, Henriquez ARB, Alvarado MC, Davila MJ (2013) Blood biochemistry of the breeding population of green turtles (Chelonia mydas) in the Aves Island Wildlife Refuge, Venezuela. S Am J Herpetol 8:147-154

R Core Team (2017) R: a language and environment for sta-

Editorial responsibility: Sandra Hochscheid,

Naples, Italy tistical computing. R Foundation for Statistical Computing, Vienna

Reséndiz E, Flores-Ramírez S, Koch V, Cordero-Tapia A (2016) First record of fibropapillomatosis in a green turtle Chelonia mydas from the Baja California peninsula. J Aquat Anim Health 28:252-257

* Sella KAN, Fuentes MMPB (2019) Exposure of marine turtle nesting grounds to coastal modifications: implications for management. Ocean Coast Manag 169:182-190

Shamblin BM, Bagley DA, Ehyhart LM, Desjardin NA and others (2015) Genetic structure of Florida green turtle rookeries as indicated by mitochondrial DNA control region sequences. Conserv Genet 16:673-685

Stacy NI, Innis CJ (2017) Clinical pathology. In: Manire CA, Norton TM, Stacy BA, Innis CJ, Harms CA (eds) Sea turtle health and rehabilitation. J. Ross Publishing, Plantation, FL, p 147-207

Stacy NI, Alleman R, Sayler KA (2011) Diagnostic hematology of reptiles. Clin Lab Med 31:87-108

* Tucker AD, Read MA (2001) Frequency of foraging by gravid green turtles (Chelonia mydas) at Raine Island, Great Barrier Reef. J Herpetol 35:500-503

Tukey JW (1977) Exploratory data analysis. Addison-Wesley Publishing Company, Reading, PA

*Valverde RA, Owens DW, MacKenzie DS, Amoss SM Jr (1999) Basal and stress-induced corticosterone levels in olive ridley sea turtles (Lepidochelys olivacea) in relation to their mass nesting behavior. J Exp Zool 284:652-662

Velguth KE, Payton ME, Hoover JP (2010) Relationship of hemoglobin concentration to packed cell volume in avian blood samples. J Avian Med Surg 24:115-121

Wallace BP, DiMatteo AD, Hurley BJ, Finkbeiner EM and others (2010) Regional management units for marine turtles: a novel framework for prioritizing conservation and research across multiple scales. PLOS ONE 5:e15465

Wickham H (2016) Ggplot2: elegant graphics for data analysis. Springer-Verlag, New York, NY

Submitted: September 10, 2019; Accepted: March 30, 2020

Proofs received from author(s): April 30, 2020 